The University of San Francisco

USF Scholarship: a digital repository @ Gleeson Library |

Geschke Center

School of Education Faculty Research

School of Education

2016

\title{
Human Rights and Education Policy in South Asia
}

Monisha Bajaj

University of San Francisco, mibajaj@usfca.edu

H Kidwai

Follow this and additional works at: http://repository.usfca.edu/soe_fac

Part of the International and Comparative Education Commons, and the Social and Philosophical Foundations of Education Commons

\section{Recommended Citation}

Bajaj, M. \& Kidwai, H. (2016). Human rights and education policy in South Asia. In K. Mundy, A. Green, R. Lingard \& A. Verger (Eds.) Handbook of global education policy (pp. 206-223). Hoboken, NJ: Wiley-Blackwell. ISBN: 9781118468050.

http://dx.doi.org/10.1002/9781118468005.ch11

This Book Chapter is brought to you for free and open access by the School of Education at USF Scholarship: a digital repository @ Gleeson Library | Geschke Center. It has been accepted for inclusion in School of Education Faculty Research by an authorized administrator of USF Scholarship: a digital repository@ Gleeson Library | Geschke Center. For more information, please contact repository@usfca.edu. 


\title{
Chapter 11
}

\section{Human Rights and Education Policy in South Asia}

\author{
Monisha Bajaj and Huma Kidwai
}

\section{Introduction}

The rise of the human rights framework over the past seven decades has influenced diverse sectors including education. The forces of globalization and human rights are reflected differentially in educational policy discussions, textbook revisions, teacher education, and in the everyday life of schools across the South Asian region, comprising the diverse nations of Afghanistan, Bangladesh, Bhutan, India, the Maldives, Nepal, Pakistan, and Sri Lanka. The adoption of the Universal Declaration of Human Rights (UDHR) in 1948, arguably the cornerstone document of the global rights framework, occurred around the same time as the independence of many South Asian nations from British rule. Three South Asian nations were among the original 40 signatories to the UDHR (Afghanistan, India, and Pakistan), preceding the independence of most nations in sub-Saharan Africa and elsewhere in the global South. In more recent years, rights discourses, referred to in this chapter synonymously as "rights talk," have influenced donor aid as well as local movements towards policy reform in education in the region (see also Bajaj 2012; 2014). ${ }^{1}$

One of the most common shifts in international educational policy discourse is the assertion of rights-based claims that education, in and of itself, is an entitlement alongside the decades-old conditional and cost-benefit analyses of schooling namely, human capital theory and rate of return analyses (Perkins 2001; Psacharopoulos 1996; Schultz 1961; 1980). Rights-based approaches emphasize marginalized and hard-to-reach populations, such as ethnic minorities, certain religious groups, and disabled children, viewing their access to schooling as a fundamental component of their guarantees as citizens and human beings (UNESCO 2010). International documents increasingly count out-of-school children in global, rather 
than purely national, terms, highlighting the efforts towards Education for All (EFA) launched through the 1990 (Jomtien) and 2000 (Dakar) summits, the Millennium and Sustainable Development Goals $(2000 ; 2015)$ and subsequent meetings.

In this chapter, we seek to chart the rise of rights talk in global educational policy and map it onto educational development and national policy formation in the diverse nations of South Asia. Discourses of educational rights circulate globally and have been shaped through international meetings and conventions; as they circulate, government actors, non-governmental organizations (NGOs), and local activists anchor such discourses in unique ways resulting in distinct localized meanings when examined closely. Looking past the similar language utilized, the nation states of South Asia have varied histories and trajectories - as well as different relationships with donor countries due to geopolitical shifts during the Cold War and, soon after its demise, the post-September 11, 2001 influx of aid to parts of the region. We argue that education reforms are deeply linked to nation states' integrations and alliances in the global community, as is evidenced through policy-making and educational development across and within each country discussed in this chapter.

For this chapter, we relied on various sources to frame our argument and analysis. First, we each drew on our many years of experience as educational scholars and practitioners in the South Asian region. Second, we identified key policy documents to review from each of the eight nations in South Asia. We noted how, where, and when human rights discourses were (and were not) utilized, hypothesizing together on "why" such language was engaged. There is a lack of available, organized, and rigorous evidence on the impact of the human rights framework on education policies in South Asian countries. To overcome this lacunae in organized research on the subject, we drew from a variety of sources, including: (a) government: policy reports, research publications, and briefs, as well as the content from their official websites; (b) civil society: reports, petitions, blogs, white papers, policy reviews, and the like; (c) bi- and multi-lateral organizations: education reviews, project reports, thematic case studies, statistical databases; (d) media: news reports and articles; and (e) academic research and literature, such as published articles, books, and dissertations.

The sections that follow offer perspectives on how rights discourses influence contemporary educational policy-making in South Asia. We have given primacy to the policy and discursive level in order to substantiate comparisons across the eight nations of the subcontinent that currently constitute over one-fifth of the world's population. Without sustained investigation at the local levels in each nation, it would be unfair to offer evidence on implementation or divergence between policy and practice. Instead, we seek to compare policy, with an eye toward continuities and discontinuities vertically from the global to the national, and horizontally from nation to nation in the region. ${ }^{2}$

\section{The Rise of Rights Talk in Global Education Policy}

Over the past seven decades, education has increasingly been framed as a human right in global policy discussions, valuable in and of itself, as opposed to solely an instrumental mechanism for economic development. The modern rise of human rights in the post-World War II era can be traced to the establishment of the United Nations (UN) in 1945 and the adoption of the Universal Declaration of Human 
Rights (UDHR) in 1948. The right to free and compulsory primary education provided by national governments was enshrined in this seminal document:

\begin{abstract}
Article 26: (1) Everyone has the right to education. Education shall be free, at least in the elementary and fundamental stages. Elementary education shall be compulsory. Technical and professional education shall be made generally available and higher education shall be equally accessible to all on the basis of merit. (2) Education shall be directed to the full development of the human personality and to the strengthening of respect for human rights and fundamental freedoms. It shall promote understanding, tolerance and friendship among all nations, racial or religious groups, and shall further the activities of the United Nations for the maintenance of peace. (3) Parents have a prior right to choose the kind of education that shall be given to their children. (UDHR, UN 2014) $)^{3}$
\end{abstract}

Subsequent conventions and agreements, such as the UN International Covenant on Economic, Social and Cultural Rights (1976), the UN Convention on the Rights of the Child (1989), the Education for All Frameworks (1990 and 2000), and the Millennium and Sustainable Development Goals (MDGs and SDGs), have further elaborated the conditions and benchmarks for access, quality, equity, and accountability in educational provision.

Globalization and the global flow of ideas have resulted in rights-based approaches infusing, at least discursively, national education policies worldwide over the past several decades through various "top-down" inter-governmental meetings and "bottom-up" strategies by civil society advocates seeking to expand and improve educational access and quality (Bajaj 2012; Mundy and Murphy 2001; Mundy 2008). Human rights are largely discussed vis-à-vis education in three interrelated ways: (a) education as a human right; (b) education with human rights and dignity; and (c) education for human rights (Bajaj 2014).

Positing access to schooling as a human right has provided rights-bearers the ability, at least in theory, to hold governments accountable. Rights frameworks also facilitate the agency of children and their families in demanding their right to schooling as opposed to being passive beneficiaries or targets of interventions (typically framed in larger efficiency terms rooted in arguments for economic development) (McCowan 2013; Robeyns 2006).

Critiques of the rights framework in education often focus on the limited entitlement offered by international declarations and meetings, "access to primary schooling," rather than a more comprehensive vision of rights to further secondary and tertiary education, food, work, social security, etc. Additionally, the inordinate focus on access, at least in the MDGs, has also been critiqued for its myopia to questions of overcrowding, lack of resources in schools, and consequent poor quality education that does not benefit children (and may actually put them at heightened risk, particularly girls, as they attend crowded schools with limited adult supervision) (Mirembe and Davies 2001). Still, the contemporary framing of access to education as a human right demonstrates the potential of globalization to diffuse ideas and frameworks internationally. International organizations, such as the United Nations Children's Fund (UNICEF), have declared and promoted the view that, "Education is not a static commodity to be considered in isolation from its greater context; it is 
an ongoing process and holds its own inherent value as a human right" (UNICEF 2007, xii, as cited in Bajaj 2014).

From the vantage point of the global South, in the years after independence from colonial rule, access to schooling shifted from an elite concern to part of broader national visions for advancing integration and social cohesion (however slowly and partially realized) (Meyer et al. 1992). Post-World War II, as the process of decolonization began in parts of Asia and Africa, the deepening of Western schooling in newly independent nations corresponded with international calls for equitable and broad access to schooling regardless of whether rights justifications were utilized locally for such decisions (Boli et al. 1985; Fuller 1991). For example, India's first Prime Minister Jawaharlal Nehru governed a largely illiterate populace (only $16.7 \%$ of Indians could read or write basic texts at the time of independence in 1947); he thus advocated for schooling as an engine of economic growth, national cohesion, and self-reliance, resonating with global discourses of schooling as an integral factor in human capital development (Becker 1964) and human rights.

\section{Educational Development in South Asia}

South Asia has experienced rapid and robust economic growth since the early 1990s. Manifestations of this growth can be seen in declining poverty rates and significant improvements in human development (Dreze and Sen 2013). The percentage of people living on less than US\$1.25 a day fell in South Asia from $61 \%$ in 1981 to $36 \%$ in 2008 (World Bank 2013a). This progress in relation to the mounting pressure to view development from a rights-based approach, and donor aid conditioned on policies that reflect this, has created a receptive political environment for adopting EFA goals and policies. Given the plethora of challenges facing the South Asian region - a large proportion of the world's population, the largest number of poor and undernourished children, and several "fragile" states of geopolitical significance (World Bank 2013a) - South Asia has and will continue to play an important role in the global development story providing new dimensions to both discourse and implementation related to educational provision.

South Asian countries have espoused diverse responses to political and economic realities since the end of the Cold War and notably post-9/11, with foreign funding being channeled to Pakistan and Afghanistan along with military involvement in those countries. While some countries, like India, previously asserted their "nonalignment," others, such as Afghanistan, have had education and curriculum closely tied to the political realities of distinct historical moments, ranging from Soviet rule to the Taliban to current US influences on educational reforms. From early on, nations of the subcontinent have recognized the value of education, despite differences in how schooling has been mandated legally.

Global commitments to education through landmark meetings and declarations have incrementally provided a strong push towards education becoming a key component of policy discourse locally. In India, Sarva Shiksha Abhiyan (SSA) - operational since 2000 and with a near US\$10 billion budget in 2013 - is the overarching program under which different education programs are designed and implemented at the central as well as the state levels, where the majority of educational planning occurs. While some attention has been paid to improving the quality of education in schools, the predominant focus of SSA has been to increase enrollments in primary schools. 
Education surveys from the 1990s show abysmally low levels of achievement for most countries in South Asia (De et al. 2011, UNICEF 2011; Dreze and Sen 2013; World Bank 2015). However, the decades following the Jomtien Education for All Declaration (1990) have witnessed tremendous change in the landscape of education, with the number of out-of-school children being halved between 1999 and 2010 in the region (UNESCO 2010); from 2002 to 2005 alone, the number of out-of-school children went from 43 to 26 million - by about 11.5 million in India, 3 million in Afghanistan, 2 million in Pakistan, and 1 million in Bangladesh. There was also a substantial increase in enrollment rates at the secondary level, though the overall numbers still remain low (see Table 11.1). At the tertiary level, enrollment rates in the region increased to $10 \%$ on average (World Bank 2013b).

Similar to many nations across the globe whether in the global North or global South, education has historically been a much lower development priority as evidenced from most South Asian countries' limited financial inputs into the sector (SIO 2013). Barring the Maldives, every other country in the region reports investing an average of $3.3 \%$ of GDP as public spending on education (see Table 11.1), placing the entire region among those with low human development on this indicator according to the United Nations (UNDP 2015a). In effect, a large share of this very limited spending is earmarked for teachers' salaries, leaving few resources for learning materials or other expenditures (De et al. 2011; World Bank 2013b). In fact, many countries, including India, Pakistan, Bangladesh, and Sri Lanka, have over the years reduced their spending on education in the face of budgetary deficits and increased spending on military functions (Chopra 2012; Shaukat 2012; UNDP 2015a). Low or reduced funding for education often goes unnoticed due to poor or unvoiced public demand for quality education that characterizes most countries in the region (Satya 2011). Recent legislation in the region, such as India's Right to Education Act, recasts citizens as rights-bearers, as opposed to passive beneficiaries of state services, yet vibrant social movements with marginalized citizens acting together to demand their rights have yet to emerge on a broad scale. The mismatch between policy discourse and actual implementation is beyond the scope of this chapter, but suffice to note that despite rights talk infusing policy documents, greater citizen-led accountability efforts are still required. ${ }^{13}$

While South Asian countries have issued national educational policies and frameworks periodically since Independence, rights talk began to infuse these documents in the 1990s, coinciding with the Jomtien Education for All Summit (1990) and the ratification by all eight South Asian nations of the UN Convention on the Rights of the Child (Bhutan and Bangladesh were among the first 20 nations to both sign and ratify the Convention in 1990).

\section{Transnational Advocacy Networks in Education}

A useful framework for understanding and interpreting the diverse manifestations and forms of rights discourses in South Asian educational policies is political scientists Margaret Keck and Kathryn Sikkink's (1998) notion of the boomerang effect of transnational advocacy networks. In their conceptualization, the authors 
Table 11.1 Education in South Asia

\begin{tabular}{|c|c|c|c|c|c|c|c|c|}
\hline & Afghanistan & Bangladesh & Bhutan & India & Maldives & Nepal & Pakistan & Sri Lanka \\
\hline Population (millions) 2014 & 31.3 & 158.5 & 0.77 & 1267.4 & 0.35 & 28.1 & 185.1 & 20.70 \\
\hline $\begin{array}{l}\text { Urbanized population (\%), } \\
2014\end{array}$ & 26 & 34 & 38 & 32 & 44 & 18 & 38 & 18 \\
\hline $\begin{array}{l}\text { Pop. below poverty line of } \\
\text { US\$1.25/day (\%) } \\
2006-2012\end{array}$ & - & 43.3 & 2.4 & 23.6 & - & 23.7 & 12.7 & 7 \\
\hline $\begin{array}{l}\text { Human Development Index } \\
\text { category, } 2014\end{array}$ & Low & Medium & Medium & Medium & Medium & Low & Low & High \\
\hline $\begin{array}{l}\text { Total adult literacy rate }(\%) \\
2007-2011, \text { male/female }\end{array}$ & $39.5 / 12.5$ & $61 / 52$ & $\begin{array}{l}65 / 38.7 \\
(2005)\end{array}$ & $66 / 60$ & $98.4 / 98.4$ & $73 / 48$ & $69 / 40$ & $93 / 90$ \\
\hline Mean years of schooling, 2014 & 3.21 & 5.07 & 2.3 & 4.43 & 5.84 & 3.24 & 4.73 & 10.8 \\
\hline $\begin{array}{l}\text { Primary gross enrolment ratio } \\
\text { (\%) 2008-2012, male/ } \\
\text { female }\end{array}$ & $114 / 81$ & 98/106 (2004) & $110 / 112$ & $116 / 116$ & $111 / 107$ & - & $104 / 85$ & $99 / 99$ \\
\hline $\begin{array}{l}\text { Primary completion ratio (\%), } \\
2009 / 2013 \text {, male/female }\end{array}$ & $48 / 19$ & $70 / 80$ & $96 / 101$ & $96 / 97$ & $111 / 103$ & $97 / 107$ & $79 / 67$ & $98 / 97$ \\
\hline $\begin{array}{l}\text { Secondary gross enrolment ratio } \\
\text { (\%) 2008-2011, male/female }\end{array}$ & $60 / 30$ & $48 / 55$ & $69 / 71$ & $66 / 60$ & $\begin{array}{l}71 / 75 \\
(2005)\end{array}$ & $46 / 41$ & $40 / 30$ & $90 / 100$ \\
\hline $\begin{array}{l}\text { Government spending on } \\
\text { education as a \% of GDP, } \\
\text { 2011-2013 }\end{array}$ & 4.6 & 2.2 & 4.7 & 3.3 & 7.2 & 4.1 & 2.2 & 2.0 \\
\hline $\begin{array}{l}\text { Constitutional guarantees for } \\
\text { the right to free and } \\
\text { compulsory education }\end{array}$ & $\begin{array}{l}\text { Partial } \\
\text { guarantee }\end{array}$ & $\begin{array}{l}\text { Partial } \\
\text { guarantee }\end{array}$ & $\begin{array}{l}\text { Partial } \\
\text { guarantee }\end{array}$ & $\begin{array}{l}\text { Full } \\
\text { guarantee }\end{array}$ & $\begin{array}{l}\text { Partial } \\
\text { guarantee }\end{array}$ & $\begin{array}{l}\text { Partial } \\
\text { guarantee }\end{array}$ & $\begin{array}{l}\text { Partial } \\
\text { guarantee }\end{array}$ & $\begin{array}{l}\text { Full } \\
\text { guarantee }\end{array}$ \\
\hline $\begin{array}{l}\text { Constitutional status of the } \\
\text { right to free and compulsory } \\
\text { education }{ }^{4}\end{array}$ & $\begin{array}{l}\text { Article }^{5} \\
\text { since } 2003\end{array}$ & $\begin{array}{l}\text { Act since } \\
1990^{6} \\
\text { (primary only) }\end{array}$ & $\begin{array}{l}\text { Article }^{7} \\
\text { since } \\
2007\end{array}$ & $\begin{array}{l}\text { Act since } \\
2009^{8}\end{array}$ & $\begin{array}{l}\text { Article }^{9} \\
\text { since } \\
2008\end{array}$ & $\begin{array}{l}\text { Article }^{10} \\
\text { since } \\
2007\end{array}$ & $\begin{array}{l}\text { Article }^{11} \\
\text { amended } \\
\text { in } 2010\end{array}$ & $\begin{array}{l}\text { Act since } \\
1945^{12}\end{array}$ \\
\hline
\end{tabular}

Source: Right to Education Project 2013; UNDP 2015a; 2015b; UNICEF 2013; World Bank 2015. 
posit that nation states may express initial reluctance for reforms, but that pressure from civil society actors in their own country who have powerful transnational alliances with international organizations and global solidarity movements can impel governments to adopt human rights-friendly policies. In the field of education, Mundy and Murphy (2001) have explored "the emergence and evolution of nongovernmental organizational forms and actors engaged in transnational advocacy" to advance education for all $(2001,125)$. The authors cite various reasons for this rise, such as new entrants into the field of education, new coalitions among local and global organizations, and "unprecedented levels of interaction ... between nongovernmental actors and intergovernmental bodies like UNESCO, UNICEF, and the World Bank" (2001, 126).

In the diverse cases of rights-based policies in South Asia - whether still under discussion and deliberation or already adopted - the boomerang effect and analyses of educational transnational advocacy networks provide useful frameworks to account for the influence of colonial legacies, historic and new foreign aid relationships, the rise of civil society actors throughout the subcontinent, and South-South cooperation across the globe and among the nations of South Asia. While it is beyond the scope of this chapter to trace the genealogy of educational policies and the diverse influences upon them in each South Asian nation, it is of significance to note the multiple roles and influences of civil society actors, donor organizations, intergovernmental agencies, and national discourses on educational policy-making in each of the country case studies that follow.

Notably, evidence of pressures from above (the international community), below (civil society and local social movements), and the effects of circulating policy discourses can be found in the trajectory of contemporary educational policy-making in South Asia. In India, the largest South Asian nation with a population of over one billion, the early 1990s, when policies adopted more rights talk, also marked a shift in economic policy, with the liberalization of trade and greater integration into the global economy. In Sri Lanka, despite having legislation on the right to education since 1945 and boasting an almost $92 \%$ adult literacy rate, national and international policy documents on education credit the international EFA movement for the revival of their commitment to improving the quality of education. Similar references are made to EFA declarations and to the MDGs in almost all the documents reviewed that were sourced from local and international NGOs, bi- and multi-lateral organizations, and academic literature for the various South Asian nations. In utilizing the same language and references, national- and local-level policy actors, as well as local social movements and NGOs, build pressure to be placed on policy decisions from above, below, and in the multi-directional way that transnational networks operate. This, however, does not mean that rights talk is used in the same way across contexts.

While human rights discourses, particularly the right to education, are influenced by global discourses that circulate, rights talk has a long history on the South Asian subcontinent. Human rights discourses have been an underlying feature of resistance and liberation movements in these countries, dating back to the anti-colonial struggles in the early- to mid-1900s. Much of the ways in which rights continue to be envisioned as something to be fought for and as platforms for social activism in South Asian countries draw from the anti-imperialist traditions from which they emerged (Cornwall and Nyamu-Musembi 2004). Given this historical context of 
rights, the role of civil society and local activists in pushing governments from below despite adoption of rights language in policy texts given global influences - offers a complex dynamic of how local actors shape and deepen the many meanings of rights domestically.

The role of civil society in both the Constitutional Amendment and the drafting and passage of India's Right to Education Act (RTE) in 2009 offers a glimpse into how civil society actors (some of whom sat on the legislation's drafting committee) indigenize international rights discourses to make them locally meaningful and legitimate (Bajaj 2014). For example, India's Right to Education Act includes provisions not necessarily commonly associated with this right: $25 \%$ of private school seats must be made freely accessible to poor children, schools must have libraries with local periodicals such as newspapers and magazines, and parent-teacher committees must include proportional representation of women and marginalized groups (Bajaj 2014). These local interpretations may diverge from common understandings globally, but have given policy actors legitimacy for advocating these measures by subsuming a variety of reforms under the umbrella of educational rights.

In most other South Asian nations, efforts to make the right to education an enforceable right under domestic law are still underway. Although confined to primary schooling, Bangladesh enacted the right to education in its Compulsory Primary Education Act in 1990. The country has made significant improvement since then in raising school participation. Compared to $71 \%$ in 1980 , the gross enrollment rate in primary schools increased to over $100 \%$ in 2004 . However, the primary school completion rate is the lowest in the region at $70 \%$ for male students and $80 \%$ for female students (see Table 11.1). Nevertheless, Bangladesh has shown enormous progress in closing the gender gap in primary and secondary enrollment to the extent that girls' enrollment has exceeded that of boys' (see Table 11.1). Although this development in raising gender parity cannot be underestimated, it points to the high prevalence of child labor that often explains poor enrollment among boys across the region (Asadullah and Chaudhury 2009). In addition, Bangladesh has sought to address female education through conditional cash transfer programs over the years, and many NGOs have worked on girls' access to education, resulting in the current reverse gender gap. The gender gap has been found to be more prominent among poor households where the female stipend programs appear to have had the most impact (Ahmed et al. 2009). Overall, poverty in Bangladesh, the highest in South Asia, is seemingly the single largest factor explaining why outcomes fail to match policy discourses on the right to (primary) education in the country.

Local actors have been central to advancing discussions on the right to education in Pakistan. Under Pakistan's 18th Constitutional amendment in 2010, Article 25A guarantees free and compulsory education, but legal frameworks and mechanisms for redress have yet to be developed (Idara-e-Taaleem-o-Aagahi 2011). A local campaign, spearheaded by Idara-e-Taaleem-o-Aagahi (ITA), one of Pakistan's leading educational organizations, has developed plans and coordinated a petition of over a million signatures to influence government policy. Additionally, a Draft Bill was prepared by the United Nations Educational, Scientific and Cultural Organization (UNESCO) and presented to the Pakistan government (UNESCO 2012). This Draft Bill was open to the public for critical review and comparative analysis, using India's recently ratified RTE Act as an example. Pakistan's right to education campaign has 
provided greater visibility for human rights discourses at the grassroots level as opposed to government pronouncements and official usage of rights talk. Young educational activist and Nobel Peace Prize Laureate (2014), Malala Yousafzai's role as an advocate and spokesperson in local and international media has highlighted gender discrepancies in educational access, further strengthening the call for a constitutional right to education nationally.

Another mechanism through which local policy-making in Pakistan is often linked with rights discourses in global agreements on education is the significant presence of international NGOs and aid agencies in the country. In 2011, Pakistan was the fourth largest recipient of US foreign aid (Center for Global Development 2012). In 2010, the United States Agency for International Development's (USAID) education program in Pakistan was its largest in the world with budgeted funds of more than US $\$ 330$ million (Birdsall 2010). Security considerations have been used to justify the prioritization of US aid to Pakistan's education sector (Birdsall 2010). The strategic use of rights talk for security-related initiatives in US foreign policy is an area that requires further scholarly attention, but it is worth noting here that rights language often infuses the rationale for military interventions as has been seen in Afghanistan and Pakistan since 2001.

\section{Educational Rights Amidst Social and Political Conflict}

Similarly positioned as a recipient of significant global aid for education, the Afghan Ministry of Education has been working in close collaboration with international agencies towards EFA goals by 2020, an extended date from the usual 2015 target given the severity of challenges facing Afghanistan's achievement of universal access and gender parity in education (Islamic Republic of Afghanistan 2011). Striving to increase enrollment and tackle profound barriers to girls' schooling, the government also faces a significant rural-urban divide (see Table 11.1).

The Afghan government is making simultaneous attempts to design a curricular policy that acknowledges local cultures and diverse realities across the country within a wider global discourse on peace and human rights. In her research on Afghan education, Jones (2007) traces the school curriculum in Afghanistan from the period of Soviet rule through the Taliban, following it to the present. She illustrates the destruction of the education system in Afghanistan for decades, partly in the name of a radical version Islam, by numerous wars fought in the country, and partly by different international and political groups trying to gain control over the nation. During this period, schools were either shut down or used to promote a curriculum ridden with the political ideologies of the ruling regime; for example, in what is now an oft-cited example, USAID funded the publication of textbooks during the Cold War with violent examples such as "My uncle has a weapon" and " J' is for "Jihad," and offered US financial support for the extremist mujahedeen in their bid to overthrow Soviet rule in the 1980s (The Economist 2012).

Despite the tumultuous history of Afghanistan's political transformations, significant changes in the education system have been brought about since the downfall of the Taliban in 2001. Efforts to revise the national curriculum have sought to link ideals of peace and human rights with concepts in Islam. The initial input for this revision was from NGOs working with and on behalf of the new 
government. In December 2002, at a national workshop facilitated by USAID, over 120 education experts from Afghanistan and other countries participated in drafting the new national curricular framework. By 2003, the government framework was approved by the Ministry of Education's Compilation and Translation Department. The new curriculum has been hailed by education researchers (Jones 2007; Georgescu 2007) for acknowledging the need for integrating new learning areas, such as "peace education, life-skills, human rights education, mine awareness, environmental education, [and] gender issues," among others (Georgescu 2007,437). The preface to the Curriculum Framework Afghanistan (Department of Compilation and Translation 2003) reiterates that the new curriculum is based on the Afghan cultural context and that, while it notes the trauma of war particularly among children, it no longer focuses on war as it did in previous textbooks and curricular approaches.

Similarly emerging from violent conflict, Sri Lanka provides a unique example in the region from the perspective of human rights discourse and high levels of educational access and literacy, an indicator of quality. Much planning for EFA in Sri Lanka is consistent with many of the Jomtien and Dakar expectations (Little 2003, 83). As noted in Table 11.1, Sri Lanka is the only country in the region to be on a par with nations with high human development in education given its near-universal literacy rate $(92 \%)$, high gross primary enrollments $(99 \%)$, and regional record for the greatest mean years of schooling (9.3 years). Arguably, in the regions most affected by the civil war and ethnic conflict, access and quality education is harder to assess given that government reports may not disaggregate data by region. While the Universal Declaration of Human Rights was adopted in 1948 with provisions for the right to education, Sri Lanka had already instituted free education for all children from primary to university (tertiary) levels in 1945 through a bill passed by thenEducation Minister Dr Kannangara prior to the nation's full political independence from Britain in 1948 (Rajapaksa 2009; Little 2010). Since the passage of the 1945 bill, it has been compulsory by law for Sri Lankan children aged 5-14 to attend school (Right to Education Project 2013); in 1997, this provision was further extended to make not only enrollment mandatory, but for attendance and completion to be as well (National Education Commission 2003).

It is difficult to trace a direct influence of global agreements on the policy and planning of Sri Lanka given their historic record of education access and attainment. According to Angela Little (2003), this was perhaps because Sri Lanka had already made considerable progress in enrollments by the time of the Jomtien EFA Conference (1990). Crediting the "democratic socialism of the pre-independence period" (2003, 10 ), which had a cumulative impact on the social development of the country, Little posits that "By the mid-1990s, national policies for primary education, especially quality improvements in primary education, were gaining ground both within the work of the high profile National Education Commission and the Ministry of Education and Higher Education. While the policies were consistent with EFA Goals, they appear not to have been influenced by them. The policy dialogue revolved around a discourse that was generated nationally and had national and intra-national referents" $(2003,19)$. Such independence in policy-making and localization within the context of the right to education, particularly given Sri Lanka's high rates of access and completion, offer a perspective that international discussions merely 
provided an echo of local efforts rather than an external impetus for educational policy reform, differing markedly from other nations in the region.

By contrast, Nepal has a very recent history of mass education and has made remarkable progress in increasing access despite political shifts and turmoil that have affected the provision of education. However, the expansion of mass schooling in the country has not yet sufficiently addressed the diversities of caste, language, gender, class, and recently, political affiliation. With frequent shifts in the political system over the past 70 years, the country has not had a consistent priority and policy in education. Historically, the monarchy in Nepal considered education the prerogative of the ruling elite and made no attempts to extend schooling to all citizens.

After the downfall of the Rana regime in 1951, mass schooling began to expand (IREWOC 2007). With the assistance of the United States Overseas Mission, in 1956 the Nepal National Educational Planning Commission suggested that the government of Nepal make primary education free and universal once the necessary infrastructure and the requisite teaching force was developed (Tuladhar n.d.). The Commission favored linguistic and cultural assimilation and suggested the Nepali language as the medium of instruction. In a country with over 97 languages and numerous other dialects, having a common language as the medium of instruction has continued to be a major impediment to facilitating the school attendance of children with diverse linguistic backgrounds (Tuladhar n.d.). These assimilationist policies excluded large sections of the population in the name of national integration until 1990 when the country transitioned from an absolute monarchy to a multi-party system (Singh and Jensen 2006). Influenced simultaneously by the EFA discussions globally, the National Education Commission of 1991, for the first time, considered the linguistic and cultural diversity of Nepal and suggested that primary education be offered in the mother tongue (Tuladhar n.d.). Donor aid for various projects, and shifting priorities by diverse regimes, has shaped Nepal's recent policy trajectory within a largely rural educational system.

\section{Localizing Educational Discourses in Small South Asian nations}

Small nations in South Asia often adopt reforms similar to their larger neighbors, in addition to - as seen in the cases of Bhutan and the Maldives - infusing educational policy and provision with the flavor of local values, customs, and religious ideals.

The trajectory of education in Bhutan presents an interesting manifestation of human rights and development relevant to the cultural values and traditions of Buddhism. Placing happiness at the core of public policy, decisions on education and other social rights are guided by the principles of Bhutan's Gross National Happiness (GNH) Index. GNH was designed in the 1970s in an attempt to define an indicator and concept that measures the quality of life or social progress in more complete terms than the commonly used gross domestic product (GDP), striking a balance between the spiritual and material values of well-being. The GNH indicators recognize nine components of happiness: (1) psychological well-being, (2) ecology, (3) health, (4) education, (5) culture, (6) living standards, (7) time use, (8) community vitality, and (9) good governance (Centre for Bhutan Studies and GNH Research 2013). This vision of holistic development is far beyond most international interpretations of human rights and education. 
Education is a key indicator and increasingly a high priority for the country. Despite the low overall literacy rates noted in Table 11.1 (65\% male and $38 \%$ female), when disaggregated by age, Bhutan's youth literacy rate (15-24 years) is $80 \%$ for young men and $68 \%$ for young women (UNICEF 2013), suggesting a trend toward greater educational attainment. Bhutan's education mission aspires to "build a broadly liberal, culturally sensitive, forward-looking, standards-based education system that combines the best of received wisdom of successive generations and the results of innovation and enterprise in the diverse fields of human endeavor" and envisions an "educated and enlightened society ... at peace with itself, at peace with the world" (Royal Government of Bhutan 2012).

The Bhutan Ministry of Education recognizes EFA goals and MDGs as a means to achieve the nation's development philosophy of enhancing "gross national happiness" (Centre for Educational Research and Development 2009). Bhutan has advanced its goal of universal access to primary education with a reported net primary enrollment ratio of $96 \%$ in 2012, up from $62 \%$ in 2000 . Gender parity at both primary and secondary levels has also significantly improved. The ratio of girls to boys at the primary level increased from $82 \%$ in 2000 to $99 \%$ in 2012 (Royal Government of Bhutan 2012, 2013). Having nearly achieved EFA goals, the government is now focusing on strengthening the quality of teaching and learning (Royal Government of Bhutan 2012). Rights talk has influenced Bhutan, given the spur in educational expansion and enrollments arguably linked to the country's commitments under EFA and the MDGs, but local concepts such as happiness and psychosocial wellbeing also have permeated Bhutanese educational discourses.

The Maldives is another example of a small country in the region, like Bhutan, that has had recent successes in the expansion of primary education. The Maldives, with near universal rates of access, has sought to address the challenge of improving the quality of education. This multi-island nation is second in the region to Sri Lanka in its human development index and economic well-being (UNDP 2013; World Bank 2012). Made up of nearly 1200 islands, the smallest South Asian country is faced with the serious challenge of reaching out to all children with consistent quality standards amidst recent political turmoil and the real possibility of climate change subsuming the entire nation under water this century (Aljazeera 2013; Carrington 2013). Additionally, the training of teachers and their deployment across the islands is a major factor impeding the quality of education in the country, leading to a decline in enrollment over the past few years (World Bank 2012). Given this situation, most policy documents and reviews of education in the Maldives emphasize the need to invest in human capital in order to sustain its provisions for quality education for all (Republic of Maldives 2013; World Bank 2011; 2012). This presents another example of the strategic use of various discourses - human capital, human rights, and capabilities - in the formulation and circulation of educational policy in the South Asian region.

\section{Horizontal Dimensions of Rights-Based Educational Policies in South Asia}

As smaller South Asian nations often feel the ripple effects of policy shifts of their larger neighbors, cases of cross-learning among South Asian countries on policy related to educational rights are on the rise. For example, the Department of 
Education in Nepal has been actively collaborating with the National University of Education Planning and Administration (NUEPA) in India in devising plans for effective decentralization (Singh and Jensen 2006). The Bangladeshi NGO, the Bangladesh Rural Advancement Committee (BRAC), the largest NGO in the world, has been active in designing flexible and adaptable schooling for marginalized and conflict-affected communities in Afghanistan and Sri Lanka in the region - as well as in East Africa - building on their over 40 years of success in improving educational outcomes in Bangladesh. Furthermore, active sections of civil society in India and Pakistan have been making an attempt to create avenues for cross-learning on development issues. The education communities in the two countries have been recognizing the similarities in their cultural and historical contexts of schooling.

While the right to education and educational access are a key area of horizontal collaboration in South Asia, there is considerable cross-learning in the area of accountability as well. One such example of a civil society partnership is the work of the Annual Status of Education Research (ASER) Centers in India and Pakistan, which conduct comprehensive research on education processes and outcomes to support evidence-based advocacy for education rights and quality. Such collaboration is greatly facilitated by donor aid. The horizontal dimensions of educational policy-making and the sharing of tools for state accountability - utilizing rights talk to galvanize aid and public support - is a particularly clear example of the "boomerang effect" in South Asia (Keck and Sikkink 1998). The international instrument developed in one South Asian nation but circulated and exported to another country in the region through international aid and advocacy linkages with private foundations, the World Bank, and other donors - is utilized by subnational actors to pressure their own governments for reform and change.

Similar attempts at linkages and the creation of regional advocacy networks have been made to connect across borders by India and Bangladesh. In 2011, during the Global Action Week in Bangladesh, education practitioners from India and Bangladesh exchanged their experiences with opportunities and challenges in implementing their respective Right to Education Acts (CREATE 2011). Increased transnational advocacy networks on the subcontinent - regionalizing Keck and Sikkink's (1998) boomerang concept - utilize similar rights language and provide a useful example of how new coalitions and networks are connecting and growing in innovative ways on the South Asian subcontinent.

\section{Concluding Thoughts}

The impact of globalization and the framing of rights language in education policy in South Asia operate in complex and diverse ways. Rights-based claims to education of course have their critiques, particularly from international and comparative education scholars writing from a capabilities perspective (Robeyns 2006; Unterhalter 2003). Robeyns finds that, despite its justice orientation, the rights framework "sounds overtly rhetorical" with governments adopting guarantees while millions of children still languish out of school $(2006,76)$. Similarly, she notes that the reduction of the right to education to merely a legal right standing alone, without any connection to a moral imperative or comprehensive plan for implementation, risks confining the right to political discourse. Where cultural or social impediments to 
educational access exist, significant racial, caste, religious, or gender gaps may still persist if rights are limited to laws on paper to be enacted by governments and absent engagement with unequal social structures and hierarchies (Bajaj 2014).

Yet, rights frameworks have become the primary organizing force for diverse actors in educational policy-making. The localization of rights talk in diverse nation states in South Asia offers a window into how policy actors make sense of globally circulating discourses as well as how civil society actors pressure national governments to respond to educational demands on the ground. A unique example of this is the drafting committee of India's Right to Education Act, which included civil society actors in the core committee that put together to draft the bill alongside policy-makers (Bajaj 2014). As neighboring countries use the framework and example of India's legislation as a model and through conversations across their borders, diverse visions of educational rights infuse new legislative forms. Rights talk is mobilized differentially by diverse actors, and may shift over time and when examined at distinct levels (international, national, local) in diverse nations. Nevertheless, the increase and permanence of rights discourses in educational policy in the region are certainly worthy of further scholarly attention (Bajaj 2014).

Rights-based arguments for educational access, quality, equity, and accountability have rivaled the efficiency and rate of return arguments of decades past (and present) in calling for the expansion of schooling worldwide. South Asian nations' experiences with codifying the Right to Education (India, Bangladesh, Pakistan), juxtaposed with historic records of educational advancement prior to global declarations (the Maldives, Sri Lanka), and nations emerging from or currently facing civil and/or political unrest (Afghanistan, Nepal, Sri Lanka), suggest diverse and powerful relationships among education, citizenship, and human development. Many nations have not met the targets set forth in the EFA and MDG agreements (nor the recently launched Sustainable Development Goals set forth). While intergovernmental agencies, NGOs, and research institutes discuss strategies post-2015, questions remain about what rights and justice claims do for families and communities. Further exploration of educational policy, particularly those mandates that espouse universal notions of human rights, is needed to better understand gaps between policy and practice and the lived experiences of youth in complex and diverse regions such as South Asia.

\section{Notes}

1 Sections of this chapter are adapted from text that originally appeared in "The Productive Plasticity of Rights: Globalization, Education and Human Rights," in Globalization and Education: Integration and Contestation Across Cultures (second edition), edited by N. Stromquist and K. Monkman, 55-69. Lanham: Rowman and Littlefield.

2 This is akin to the vertical case study approach developed by Vavrus and Bartlett (2008), though, in this case, we are comparing across (not within) nations.

3 There have been debates over parents' right to choose the form of education that children will receive and the framing of education as a fundamental right. These debates are important to keep in mind in terms of how they impact tensions and contestations in the conceptualization of the right to education. For the purposes of this chapter, however, these debates have not significantly influenced the way South Asian policy-makers have engaged discourses of education. 
4 Status to be determined by three stages: (1) Insertion/amendment of an Article in the Constitution, (2) Approval of the Bill by the Government, and (3) Passing of an Act, thereby making it a legal right.

5 Article 43: "Education is the right of all citizens of Afghanistan, which shall be provided up to the level of the B.A., free of charge by the state."

6 Article 17: "The State shall adopt effective measures for the purpose of establishing a uniform, mass-oriented and universal system of education and extending free and compulsory education to all children to such stage as may be determined by law."

7 Article 9(16). "The State shall provide free education to all children of school going age up to tenth standard (grade) and ensure that technical and professional education shall be made generally available and that higher education shall be equally accessible to all on the basis of merit."

8 Article 21A: "The State shall provide free and compulsory education to all children of the age of six to fourteen years in such manner as the State may, by law, determine."

9 Article 36(b): "Primary and secondary education shall be freely provided by the State."

10 Article 17(2): "Every citizen shall have the right to receive free education from the State up to secondary level as provided for in the law."

11 Article 25A: "The State shall provide free and compulsory education to all children of the age of five to sixteen years in such a manner as may be determined by law."

12 Article 27: “...complete eradication of illiteracy and complete assurance to all persons of the right to universal and equal access to education at all levels."

13 An NGOin India, the ASER Centre, which is part of the larger educational organization Pratham, developed a learning tool for language and mathematics to assess the quality of learning (as opposed to just rates of access). "Aser" means "impact" in Hindi and also stands for the Annual Status of Education Reports conducted by the organization. These annual reports have found that less than $50 \%$ of 5 th standard (grade) students are able to read a simple standard two-level passage. Since launching the first annual report in 2005, ASER's model has been replicated in other parts of South Asia, such as Pakistan, and sub-Saharan Africa, offering communities greater information about how government schools fare. Citizen activists and policy-makers then have the ability to use this information for interventions and reform, which many have begun to do (Russell and Bajaj 2014).

\section{References}

Ahmed, M., S.A. Kazi, N.I. Khan, and R. Ahmed. 2007. "Access to Education in Bangladesh: Country Analytic Review of Primary and Secondary Education." Consortium for Research on Educational Access, Transitions and Equity (CREATE). Retrieved from: www.createrpc.org/pdf_documents/Bangladesh_CAR.pdf (accessed November 10, 2015).

Aljazeera. November 11, 2013. "Maldives Sinks into Greater Political Crisis." Retrieved from: www.aljazeera.com/news/asia/2013/11/maldives-sinks-into-deeper-politicalcrisis-2013111185028484704.html (accessed November 10, 2015).

Asadullah, M.N. and N. Chaudhury. 2009. "Reverse Gender Gap in Schooling in Bangladesh: Insights from Urban and Rural Households.” Journal of Development Studies, 45(8): 1360-1380.

Bajaj, M. 2012. Schooling for Social Change: The Rise and Impact of Human Rights Education in India. New York, London: Bloomsbury.

Bajaj, M. 2014. "The Productive Plasticity of Rights: Globalization, Education and Human Rights," in Globalization and Education: Integration and Contestation Across Cultures (second edition), edited by N. Stromquist and K. Monkman, 55-69. Lanham: Rowman and Littlefield.

Becker, G. 1964. Human Capital. Chicago: University of Chicago Press.

Birdsall, N. 2010. “U.S. Development Assistance to Pakistan's Education Sector (Fifth Open Letter to Ambassador Richard Holbrooke).” CGD. Retrieved from: www.cgdev.org/ 
publication/us-development-assistance-pakistan $\%$ E2\% $80 \% 99$ s-education-sector-fifthopen-letter-ambassador (accessed November 10, 2015).

Boli, J., J. Meyer, and F. Ramirez. 1985. "Explaining the Origins and Expansion of Mass Education." Comparative Education Review, 29(2): 145-170.

Carrington, D. 2013. "The Maldives, a Fledgling Democracy at the Vanguard of Climate Change." The Guardian, September 26, 2013. Retrieved from: www.theguardian.com/ environment/2013/sep/26/maldives-democracy-climate-change-ipcc (accessed November 10, 2015).

Centre for Bhutan Studies and GNH Research. 2013. "Gross National Happiness.” Retrieved from: www.grossnationalhappiness.com (accessed November 10, 2015).

Centre for Educational Research and Development. 2009. "Quality of Education in Bhutan: Proceedings of National Seminar.” Retrieved from: www.pce.edu.bt/sites/default/files/ Quality\%20of\%20Education\%20II.pdf (accessed November 10, 2015).

Center for Global Development. 2012. “Aid to Pakistan by the Numbers.” CGD. Retrieved from: http://international.cgdev.org/page/aid-pakistan-numbers (accessed November 10, 2015).

Chopra, R. December 17, 2012. "India's Education-for-All Dream Comes to a Halt as CashStrapped Government Slashes RTE Budget." India Today. Retrieved from: http://indiatoday. intoday.in/story/cash-strapped-government-shaves-right-to-education-budget$\mathrm{hrd} / 1 / 238105 . \mathrm{html}$ (accessed November 10, 2015).

Cornwall, A. and C. Nyamu-Musembi. 2004. "Putting the 'Rights-Based Approach' to Development into Perspective." Third World Quarterly, 25(8): 1415-1437.

CREATE. 2011. "Round Table on Right to Education: Ensuring Access with Equity and Quality.” Retrieved from: www.create-rpc.org/events/reports/Bangladeshconferencereport May2011.php (accessed November 10, 2015).

De, A., R. Khera, M. Samson, and S. Kumar. 2011. Probe Revisited: A Report On Elementary Education In India. New Delhi: Oxford University Press.

Department of Compilation and Translation. 2003. Curriculum Framework Afghanistan. Retrieved from: www.academia.edu/2914344/The_Curriculum_Framework_for_Primary_ and_Secondary_Education_Afghanistan_(accessed November 10, 2015).

Dreze, J. and A. Sen. 2013. An Uncertain Glory: India and its Contradictions. New Delhi: Penguin/Allen Lane.

Fuller, B. 1991. Growing Up Modern. New York, London: Routledge.

Georgescu, D. 2007. "Primary and Secondary Curriculum Development in Afghanistan." Prospects, 37: 427-448.

IREWOC. 2007. “Deprived Children and Education: Nepal.” Retrieved from: www.crin.org/ docs/Nepal_Education.pdf (accessed November 10, 2015).

Islamic Republic of Afghanistan. 2011. "Response to EFA Global Monitoring Report - 2011.” Ministry of Education. Retrieved from: http://moe.gov.af/Content/files/077_GMR_ ResponseV,\%20English.pdf (accessed November 10, 2015).

Idara-e-Taleem-o-Aagahi. 2011. "Report on 'Right to Education' in Pakistan: A Draft for Discussion.” Retrieved from: www.itacec.org/document/Right\%20to\%20Education_ Report\%20final\%20ITA.pdf (accessed November 10, 2015).

Jones, A.M.E. 2007. "Muslim and Western Influences on School Curriculum in Post-War Afghanistan.” Asia Pacific Journal of Education, 27(1): 27-40.

Little, A.W. 2003. "Education for All: Policy and Planning: Lessons from Sri Lanka." Department for International Development. Retrieved from: www.ioe.ac.uk/about/ documents/educationforalledpaper46.pdf (accessed November 10, 2015).

Little, A.W. 2010. “The Politics and Progress of Basic Education in Sri Lanka." Retrieved from: www.create-rpc.org/pdf_documents/PTA38.pdf (accessed November 10, 2015).

Keck, M.E. and K. Sikkink. 1998. Activists Beyond Borders: Advocacy Networks In International Politics. Ithaca: Cornell University Press.

McCowan, T. 2013. Education as a Human Right: Principles for a Universal Entitlement to. Learning. London: Bloomsbury. 
Meyer, J., F. Ramirez, and Y. Nuhoḡlu Soysal. 1992. "World Expansion of Mass Education, 1870-1980." Sociology of Education, 65(2): 128-149.

Mirembe, R. and L. Davies. 2001. "Is Schooling a Risk? Gender, Power Relations, and School Culture in Uganda." Gender and Education, 13: 401-416.

Mundy, K. 2008. "Civil Society and its Role in the Achievement and Governance of 'Education for All." Background Paper prepared for the Education for All Global Monitoring Report 2009. Paris: UNESCO.

Mundy, K. and L. Murphy. 2001. "Transnational Advocacy, Global Civil Society? Emerging Evidence from the Field of Education." Comparative Education Review, 45(1): 85-126.

National Education Commission, Sri Lanka. 2003. "Summary of Recommendations." Retrieved from: http://nec.gov.lk/wp-content/uploads/2014/04/National_Policy_2003.pdf (accessed November 10, 2015).

Perkins, D.H. 2001. Economics of Development (fifth edition). New York: Norton.

Psacharopoulos, G. 1996. Human Capital Underdevelopment: The Worst Aspects. Washington, DC: The World Bank.

Rajapaksa, S. 2009. "Human Rights Commission of Sri Lanka: Human Rights Education in Schools Mandate." Asia-Pacific Human Rights Information Center. Retrieved from: www. hurights.or.jp/archives/pdf/education12/hreas-12-03-srilanka.pdf (accessed November 10, 2015).

Republic of Maldives. 2013. "Maldives Enhancing Education Development Project: Environmental and Social Assessment and Management Framework." Ministry of Education. Retrieved from: www.moe.gov.mv/wp-content/uploads/2013/05/MEEDP-ESAMF-March2013.pdf (accessed November 10, 2015).

Right to Education Project. 2013. "National Constitutional Provisions - Sri Lanka: Education." Retrieved from: www.right-to-education.org/country-node/395/country-constitutional (accessed November 10, 2015).

Robeyns, I. 2006. "Three Models of Education: Rights, Capabilities and Human Capital." Theory and Research in Education, 4(1): 69-84.

Royal Government of Bhutan. 2012. “Annual Education Statistics - 2012.” Ministry of Education. Retrieved from: www.education.gov.bt/documents/10156/12525/AES+2012-1 (accessed November 10, 2015).

Royal Government of Bhutan. 2013. "SAARC Development Goals: Country Report." Retrieved from: www.gnhc.gov.bt/wp-content/uploads/2013/10/SDG-Country-report-20132. pdf (accessed November 10, 2015).

Russell, S.G. and M. Bajaj. 2014. "Schools, Citizens and Nation-States," in Education and International Development: Practice, Policy and Research, edited by E. Unterhalter and T. McCowan, 93-109. London: Bloomsbury.

Satya. 2011. "The Need for Political Innovation to Make Education a Top Political Priority." Education in India. Retrieved from: http://prayatna.typepad.com/education/2011/02/politicalinnovation-to-make-education-a-top-political-priority.html (accessed November 10, 2015).

Schultz, T. 1961. "Investment in Human Capital." American Economic Review, 51(1): 1-17. Schultz, T. 1980. "Nobel Lecture: The Economics of Being Poor." The Journal of Political Economy, 88(4): 639-651.

Shaukat, A. October 16, 2012. "Pakistan Risks Missing Education for all Target." The Express Tribune.Retrievedfrom:http://tribune.com.pk/story/452119/pakistan-risks-missing-primaryeducation-for-all-target (accessed November 10, 2015).

Singh, R.B. and K. Jensen. 2006. "Nepal Education Sector: Planning for Results in an Unstable Setting.” MfDR Principles in Action: Sourcebook on Emerging Good Practices. Retrieved from: www.mfdr.org/Sourcebook/3-1stEdition.html (accessed November 10, 2015).

SIO. 2013. "All Political Parties Must Include Education as an Important Subject in their Agenda." Retrieved from: http://sio-india.org/all-political-parties-must-include-educationas-an-important-subject-in-their-agenda-demands-cac-sio-of-india (accessed November $10,2015)$. 
The Economist. 2012. “Textbooks from Afghanistan: Not yet History.” Retrieved from: www. economist.com/blogs/banyan/2012/11/textbooks-afghanistan (accessed November 10,2015).

Tuladhar, G. (n.d.). "Status of Education in Nepal and Development Plan." Retrieved from: http://web.isc.ehime-u.ac.jp/ice/6-1@Gangalal\%20Tuladhar_text\%20_8p.pdf (accessed November 10, 2015).

UN. 2014. "The Universal Declaration of Human Rights.” Retrieved from: www.un.org/en/ documents/udhr/index.shtml (accessed November 10, 2015).

UNDP. 2013. “Country Profiles and Human Development Indicators.” Retrieved from: http:// hdr.undp.org/en/countries (accessed November 10, 2015).

UNDP. 2015a. "Public Expenditure on Education (\% of GDP) (\%)." Retrieved from: http:// hdr.undp.org/en/content/expenditure-education-public-gdp (accessed November 10, 2015).

UNDP. 2015b. “International Human Development Indicators.” Retrieved from: http://hdr. undp.org/en/countries (accessed November 10, 2015).

UNESCO. 2010. “2010 Global Monitoring Report: Reaching the Marginalized.” Paris: UNESCO.Retrievedfrom:www.unesco.org/new/en/education/themes/leading-the-internationalagenda/efareport/reports/2010-marginalization (accessed November 10, 2015).

UNESCO. 2012. "UNESCO Hails Passage of Right of Free Education Bill by the Senate in Pakistan.” Retrieved from: www.unescobkk.org/education/news/article/unesco-hails-passageof-right-to-free-education-bill-by-the-senate-in-pakistan (accessed November 10, 2015).

UNICEF. 2011. "Disparities in Education in South Asia: A Resource Tool Kit." UNICEF Regional Office for South Asia. Retrieved from: www.unicef.org/rosa/Countering Disparities_in_Education_Toolkit_2011.pdf (accessed November 10, 2015).

UNICEF. 2013. "Info by Country: South Asia." Retrieved from: www.unicef.org/infoby country/southasia.html (accessed November 10, 2015).

Unterhalter, E. 2003. "Education, Capabilities and Social Justice." Retrieved from: http:// unesdoc.unesco.org/images/0014/001469/146971e.pdf (accessed November 10, 2015).

Vavrus, F. and L. Bartlett. 2008. Critical Approaches to Comparative Education: Vertical Case Studies from Africa, Europe, the Middle East, and the Americas. New York: Palgrave Macmillan.

World Bank. 2011. "Human Capital for a Knowledge Society: Higher Education in the Maldives.” Human Development Unit: South Asia Region. Retrieved from: http:// siteresources.worldbank.org/INTSOUTHASIA/Resources/Human_capital_for_a_ knowledge_society_higher_education_in_the_Maldives.pdf (accessed November 10, 2015).

World Bank. 2012. "Human Capital for a Modern Society: General Education in the Maldives.” Human Development Unit: South Asia Region. Retrieved from: www-wds. worldbank.org/external/default/WDSContentServer/WDSP/IB/2012/10/03/000333037_20 121003020650/Rendered/PDF/729930WP0Maldi0IC0discloed010010120.pdf (accessed November 10, 2015).

World Bank. 2013a. "South Asia Overview." Retrieved from: www.worldbank.org/en/region/ sar/overview (accessed November 10, 2015).

World Bank. 2013b. "Brief on Education in South Asia.” Retrieved from: http://web.worldbank. org/WBSITE/EXTERNAL/COUNTRIES/SOUTHASIAEXT/0,,contentMDK:21487829 pa gePK:146736 piPK:146830 theSitePK:223547,00.html (accessed November 10, 2015).

World Bank. 2015. "Databank: Education.” Retrieved from: http://data.worldbank.org/topic/ education (accessed November 10, 2015). 